\title{
The Age of Fishes and the Rate at which they Grow.
}

Being the Presidential Address delivered before the Devonstire Association for the Advancement of Science, Literature and Art at the Plymouth Meeting, 18th July, 1916.

By

E. J. Allen, D.Sc., F.R.S.

Director of the Plymouth Laboratory.

[Reprinted from the Transactions of the Devonshire Association.]

With Figures 1-9 in the Text.

AT a time like the present, when the Empire we have inherited stands facing a crisis of its fate, when indeed the whole structure of civilization as we know it has seemed to sway, when that which generations of earnest thinkers have dreamt of as the progress of the race recoils before the forces it has itself unchained, it is difficult to restrain a feeling of incongruity in discussing any subject that has no obvious bearing on the greater problems of the hour. But I am convinced that we are following the right course in carrying on, with such help as remains available, the work of this Association, whose object is the advancement of Science, Literature and Art. In the short, swift cataracts of war, no less than in the gentler, steadier flow of peace, these matters of the mind have still their power.

In selecting a subject upon which to address you it has seemed to me best not to attempt to travel beyond the limits of that branch of Science with which my own studies have been chiefly concerned, and the science of Marine Biology is one which has special claims on a Devonshire Society. The work of Colonel Montagu at the beginning of the nineteenth century, which gave us the first descriptions of so many of our British marine animals, and by the acuteness and accuracy of its observations laid the foundation of future knowledge of their habits and life-histories, was practically all carried out in the Salcombe and Kingsbridge estuaries. Dr. Leach, the pioneer in the study of British Crustacea, was born at Hoe Gate House, within a few yards of Plymouth Hoe, and some of his collections still find a home in the museum of the Plymouth Athenæum. Philip Gosse studied the shore life of our Devonshire coast at Torquay and at Ilfracombe, and his book on those British Anemones, which he 
found in such profusion at both these spots, remains a classic. It was at Plymouth that Spence Bate first followed the remarkable transformations that occur in the development of the common crab of our shores, and it was here that he procured a large part of the material upon which was based the monograph on British Sessile-eyed Crustacea, which he wrote in collaboration with Westwood.

It was due to the wealth of marine life discovered by these and many other local naturalists, that when in 1884 an Association, chiefly under the influence of the biologists connected with the Universities of Oxford, Cambridge and London, was founded for the study of marine life and particularly for the study of marine fishes, the site of the first Laboratory was fixed at Plymouth. The researches which have been carried out at that Laboratory have fully confirmed the view that we possess off the Devon coast a fauna as extensive and as remarkable for the variety of its forms as is to be found anywhere in northern Europe.

The sea fisheries of Devonshire occupy also a unique position in the history of British Fisheries, for it was the trawl fishermen of Brixham who, gradually pressing eastwards, extended their industry to Dover, Ramsgate and Yarmouth, until finally at Grimsby and Hull they laid the foundations of that immense trade, which with the coming of the steam trawler has taken toll of the most distant waters, from Iceland and the White Sea in the north to the coast of Morocco in the south.

You will, I think, agree that it is fitting that I should here, in passing, pay a tribute to the sturdy character and indomitable courage of the men of our steam fishing fleets. The Brixham traditions have survived. Those of us who had known the men and had sailed with them in times of peace knew already something of their worth, but the cool daring and patient bravery of their work since the war began has surpassed all expectations. It is not too much to say that to them, as much as to any men, we owe the protection of our commerce from the ruthless warfare of mine and submarine.

It is now many years since the first attempts were made to apply scientific methods to the study of problems connected with sea-fisheries, and the subject has developed into what is almost a distinct department of marine biology. Were I to attempt to deal even with all the many branches of modern fishery research, it would be impossible within the limits of a single address to give more than a very superficial account of each of them. It will, I think, be more useful and offer a better prospect of securing your interest in the subject, if I confine myself to one limited question which has received in recent years a considerable amount of attention from fishery naturalists. The subject about which I propose to speak is that of the age of fishes and the rate at which they grow. It 
requires no elaborate argument to prove that the study of this matter is of the first importance if we are to give a rational account of the possible productiveness of a fishery, of the rate at which the fishery can be replenished, and of the intensity of fishing which may be prosecuted without endangering its future prospects as a means of profit to the fishermen and a source of food supply for the people.

To begin at the beginning, I need hardly remind you of the now wellknown fact that the eggs of the majority of our marketable marine fishes are small, transparent, spherical bodies, which are buoyant and float freely in the sea. The fact that the eggs of a fish are of this character, which we describe as pelagic, was first discovered by G. O. Sars in Norway, in 1864, whose observations were made on the Cod. It was discovered independently in Cornwall in 1871, in the case of the Pilchard, by that enthusiastic fisherman-naturalist and acute observer, whose name will be well known to you, the late Matthias Dunn, of Mevagissey. The only important British sea-fish which is an exception to this rule of having pelagic eggs, apart from the skates and dogfishes, whose rate of growth I propose to leave out of consideration altogether, is the Herring, the spawn of which is deposited on the sea floor and attached to shells, stones and gravel.

The time occupied in the development of the eggs of different fishes, from the time they are spawned to the time of hatching, was shown by Dannevig (5) to be dependent upon the temperature of the water in which they float, the increase in the rate of development being in direct proportion to any increase of temperature.

The following table compiled by Dannevig shows the average number of days occupied in the development of the eggs of certain species of fish at different temperatures :-

\begin{tabular}{|c|c|c|c|c|c|c|c|c|}
\hline $\begin{array}{l}\text { Temperature in Centigrade } \\
\text { Cod }\end{array}$ & $1^{\circ}$ & $+3^{\circ}$ & $4^{\circ}$ & $5^{5}$ & $6^{\circ}$ & $\mathrm{s}^{\circ}$ & $10^{\circ}$ & 12 \\
\hline (Godus morrhue) . & 42 & 23 & $20 \frac{1}{2}$ & $17 !$ & $15 \frac{1}{2}$ & 123 & $10_{2}^{1}$ & 9 \\
\hline $\begin{array}{l}\text { Whiting } \\
\text { (Gadus merlangus). }\end{array}$ & - & - & - & $15 \frac{1}{3}$ & $13 !$ & $10 \frac{1}{4}$ & 8 & $6 ?$ \\
\hline $\begin{array}{l}\text { Haddock } \\
\text { (Gadus reglefinus) ... } \\
\text { Plaice }\end{array}$ & 42 & 23 & $20 !$ & $17_{4}^{3}$ & $15 \frac{1}{2}$ & 13 & $10_{4}^{* 3}$ & 9 \\
\hline $\begin{array}{l}\text { (Plenronectes platessa) } \\
\text { Flounder }\end{array}$ & - & - & - & - & 181 & $14 !$ & 12 & 10 ? \\
\hline & - & - & - & - & $6 \frac{1}{2}$ & 51 & $4 \frac{1}{2}$ & \\
\hline
\end{tabular}

These results have since been confirmed by Johansen and Krogh (16), working with more elaborate and accurate apparatus, and they, have illustrated the relation between temperature and growth rate shown by Dannevig's figures by means of a graph, ${ }^{1}$ in which the loci of the different

1 The address was illustrated by lantern slides and the graph was shown.

NEW sErils. - vor. XI. No. 3. nRCÉmEr, 1917 . 
observations for each kind of fish lie very nearly in a straight line, which means that the increase in rate of development, over the range of temperature examined, is directly proportional to the increase in temperature.

It follows, therefore, that the actual time, under natural conditions in the sea, which an egg takes to develop, from the time it is spawned until it is hatched, is by no means constant. There are, I believe, no actual observations on the point and direct evidence as to the time occupied would not be easy to get. If we suppose that temperature is the only factor that need be considered, it is possible to deduce from the data given by the laboratory experiments the time taken in particular instances. Thus, in the waters off Plymouth, Plaice spawn from December to March. Taking the temperature at $9^{\circ} \mathrm{C}$., which is the mean for February, the coldest of the four months, the Plaice egg would, according to Dannevig's figures, ${ }^{1}$ take thirteen days to hatch. In the southern part of the North Sea, on the other hand, which is a great spawning-ground for Plaice, the mean temperature for February is $7^{\circ} \mathrm{C}$., at which temperature the eggs would take about sixteen days to hatch.

When they first emerge from the egg, the young fishes are small, transparent larvæ, whose form is very different from that of the adult fish, and the next points to consider are the time occupied by the period of transition from the larval to the adult form and the increase in size which accompanies this change of form.

In treating of this period of the life-history we will consider separately the ordinary round fishes such as Cod, Whiting, Mackerel and Herring, and flat-fishes like the Plaice, the Sole and the Turbot. In the case of the round fishes it is a little difficult to draw a sharp line of demarcation between the end of the larval and the commencement of the adult life, since both as regards structure of body and habits of life the one passes very gradually into the other.

The time occupied by the larval period may be illustrated by one or two examples. The principal spawning time of the Cod in the North Sea begins in January and is at its height in February and March. The larvæ when first hatched have a length of about $4 \mathrm{~mm}$., the length after absorption of the yolk being $4.5 \mathrm{~mm}$. At a length of $25 \mathrm{~mm}$. the adult form has practically been reached. Little cod of this size begin to appear, often hiding under the bell of a jelly-fish, from the middle of May onwards, that is to say about four months after the beginning of the spawning in January. We may say therefore with some confidence that these small cod of $25 \mathrm{~mm}$. or 1 inch in length are from three to four months old.

Some observations on larval mackerel taken off Plymouth in the summer of 1914 will illustrate the method, a somewhat laborious one, it

${ }^{1} \mathrm{Ct}$ : Apstein (1, p. 366). According to Apstein's figures the time would be nearer fourteen days at $9^{\circ} \mathrm{C}$, and serenteen days at $7^{\circ} \mathrm{C}$. 
is true, by means of which the rate of growth of these young stages may be investigated. During May, June and July a large net of fine meshthe Petersen young-fish trawl-was used at frequent intervals, chiefly between Whitsand Bay and the Eddystone, for the purpose of collecting young stages of fish. Young Mackerel first appeared on the 25th of May and they continued to be caught fairly regularly until the end of June, whilst in July only three specimens of these early stages were found during the whole month. All the specimens captured were preserved and subsequently measured. The numbers taken at any one time were small, thirty-two being the largest number in a single haul of the net, but if we combine the figures obtained from the different hauls into two groups, certain interesting features appear. The following diagram represents the figures in a graphic form, the measurements being in millimetres ${ }^{1}$ and each fish being represented by a dot :-

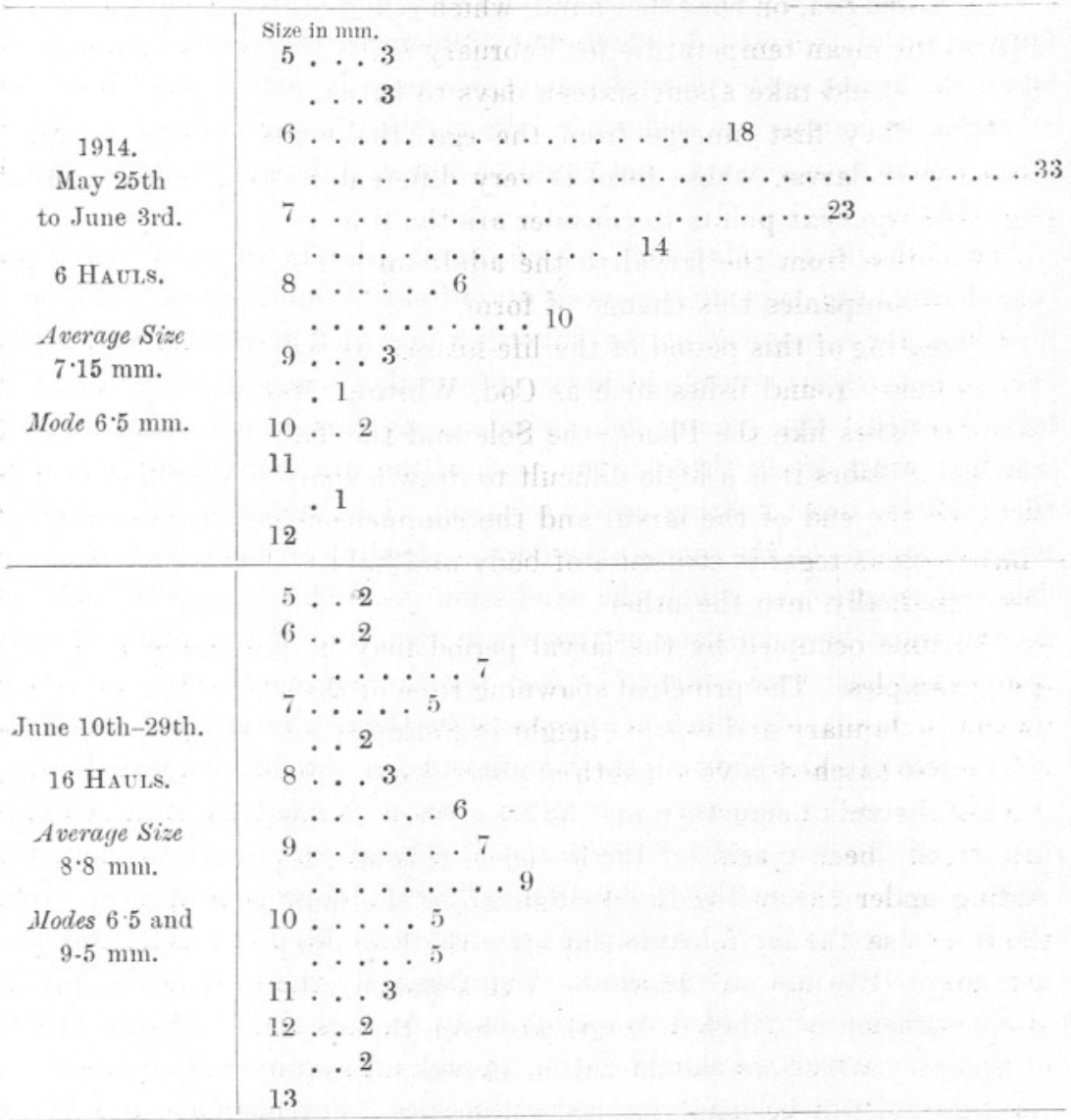

Fig. 1.-Larval Mackerel.

${ }^{1}$ A table showing the relation between British and Metric measures will be found on p. 424. 
In the first group of hauls, which we may call the end of May group, the size of greatest frequency is $6.5 \mathrm{~mm}$. and the numbers form a fairly regular curve about this mode, the average size of all the measurements being $7 \cdot 15 \mathrm{~mm}$. In the second group of hauls, the middle of June group, the numbers range themselves round two centres of frequency or modes, one at $6.5 \mathrm{~mm}$., the other at $9.5 \mathrm{~mm}$. Although the numbers are not perhaps sufficiently large to be conclusive, they at least suggest that these $9.5 \mathrm{~mm}$. fish belong to the same batch of larvæ as the $6.5 \mathrm{~mm}$. fish of the end of May group, whilst the smaller fish represent a new batch of young, derived presumably from another shoal of spawning Mackerel. If this be so, we should, I think, be not far wrong in concluding that a growth of $3 \mathrm{~mm}$. took place in the three weeks' interval from the middle of the period May 25th to June 3rd and the middle of the period June 10th to June 29th.

I give this actual instance from our own observations merely as an illustration of the way in which the problem of the rate of growth of larvæ in the sea under natural conditions may be attacked. To arrive at perfectly certain and definite results a much larger number of specimens would be necessary, and confirmation in different years would be required.

The Cod and the Mackerel, whose larval growth we have just been considering, are typical instances of ordinary round fishes. We will now look for a moment at the flat-fishes in which a distinct and rapid change both in structure and habit of life takes place at the end of the larval period. The young fish abandons its pelagic existence, during which it swam freely through the mass of the water snapping here and there at the small floating creatures upon which it feeds, and takes to lying on its side on the sand at the bottom, feeding on small worms, shellfish and crustaceans which the sand contains. This change of habit is accompanied by a twisting of the whole structure of the skull, in such a way that both eyes come to lie near together on one side of the fish, on the coloured side which is uppermost as the fish rests upon the sand.

[A series of slides showing the metamorphosis of a flat-fish was shown.]

This change in structure and habit gives us a fixed point in the lifehistory of the fish, and for the purpose in hand we require to know for what length of time the free-swimming larval stage is continued, from the time that the larva leaves the egg until it settles down as a little flatfish adapted to life on the sand. Unfortunately the evidence available is not sufficiently detailed to enable us to fix this time with the degree of accuracy which we should desire, though an approximate estimate of its duration can be made for certain species. For instance, the Plaice in the southorn part of the North Sea commences to spawn in January; 
spawning is at its height in February and continues into March. The youngest bottom stages of the Plaice, immediately after the transformation, are found in quite shallow water along the margins of sandy bays and are often taken by shrimpers, working with push nets on the shore. According to the researches of Dutch naturalists (Redeke, 20, p. 40) these small Plaice appear at the beginning of April on the Dutch coast and they become numerous in May. If, therefore, we allow two to three weeks for the eggs to hatch, we are left with about ten weeks for the larval stages. It must be admitted that this is a very indefinite statement, but it is, I think, as near as we can get on the evidence at present available. The times will doubtless vary considerably in different localities and also in different years, owing to differences of temperature and of the food-supply available.

In the case of the Sole, which was reared by Fabre-Domergue and Biétrix (6) in the laboratory at Concarneau, the pelagic larval stage lasted about seven weeks, but this of course does not give us a reliable figure for the time taken under natural conditions in the sea.

The length at which the transformation is complete and the bottom life commences is in the case of the Plaice from 14-15 mm., for the Sole it is $10-11 \mathrm{~mm}$. The sizes at the time of hatching are $6-7.5 \mathrm{~mm}$. for Plaice, $3 \cdot 2 \mathrm{~mm}$. for the Sole.

We may say in general, then, that the adult characters in most fishes are established at the end of about three months from the time of spawning, and when the length is from a quarter to half an inch.

In order to determine the rate of growth subsequent to this period various methods have been employed and for some years past considerable attention has been given to the subject. It is possible, of course, te study the matter directly by keeping fishes in confinement and measuring them from time to time. But we can get little really valuable information in that way, as it is soon seen that the rate of growth depends very largely on the conditions in which the fish are placed, on the volume of fresh seawater supplied to the tanks, on the temperature of the water, and on the amount and nature of the food which is supplied. This is an interesting study in itself, and from some points of view may prove to be of practical importance, but it really tells us little or nothing as to the rate at which the fishes grow under natural conditions in the sea, which is the point of main importance.

Dr. Petersen of Copenhagen was the first naturalist to place the study of the subject on a sound scientific basis (Petersen, 19) and the method he employed is still perhaps the most useful for dealing with the first one or two years of a fish's life. It consists simply in making a large and representative collection of the fish to be studied, from a particular 
locality and as nearly as possible at the same time, measuring the length of each individual fish and then plotting the measurements in the form of a graph or curve.

The following curve [cf. Hjort and Petersen (11), Plate IV] in which 8046 Cod, ${ }^{1}$ caught off the East Coast of Iceland in July, 1904, are graphically represented (Fig. 2), illustrates the method. Each fish was measured and the numbers found at each centimetre are plotted. It will be seen at once that the fish group themselves around certain definite lengths. The smallest sized fish in the collection was $3 \mathrm{~cm}$. long, and of this size there were 6 fish. At $4 \mathrm{~cm}$. there were 65 , and at $5 \mathrm{~cm}$. 189 . The numbers then begin to fall, there being only 43 at $6 \mathrm{~cm}$., 8 at $7 \mathrm{~cm}$., and but one fish at $8 \mathrm{~cm}$. Then they rise again until another maximum occurs at $12 \mathrm{~cm}$., with $139 \mathrm{fish}$. At $17 \mathrm{~cm}$. the number has fallen to 12 , after which another rise occurs until at $22 \mathrm{~cm}$. we have 107 . In this way the fish fall naturally into the six groups $\mathrm{O}-\mathrm{V}$. This division into size groups is due to the fact that the spawning season of the Cod in each year is a limited one, extending over only two or three months at the beginning of the year-January, February and perhaps March. By July the fish born at that time will have reached about $5 \mathrm{~cm}$. in length. The next maximum at $12 \mathrm{~cm}$. represents the fishes born the year previously, and the difference between $12 \mathrm{~cm}$. and $5 \mathrm{~cm}$., i.e. $7 \mathrm{~cm}$., expresses the growth in length during the year. Then at $22 \mathrm{~cm}$. we have the fish which have completed two full years, these fish in July when the samples were taken being two and a half years old.

Since all the fish were caught in 1904 we are able to say in what year each group was born, the $\mathrm{V}$ group, with a maximum frequency at $88 \mathrm{~cm}$., being Cod born in 1899 .

Now, although this method is satisfactory for the early years, the distinction between the groups becomes much less marked as the fish grow older, until finally the different year-groups run into one another and become indistinguishable. Fortunately, however, other methods have been discovered which enable us to attack the problem of age and rate of growth with even greater precision.

In the year 1898 Hoffbauer (13) published a paper in which he showed that the age of a fresh-water carp could be determined by an examination of the markings on the scale. In 1902 Stuart Thompson (22) published an account of some work carried out at the Plymouth Marine Laboratory in which he showed, for the first time, that a similar method was applicable to sea-fisheries, his researches having been made upon fishes of the Cod family - the Gadidæ especially on Whiting and Pollock.

1 The number of fish at $45 \mathrm{~cm}$. has been taken at forty-seven instead of ninety-seven given by Hjort, which appears to be a misprint. Forty-seven agrees with what is shown in the graph and is in accordance with expectation. 


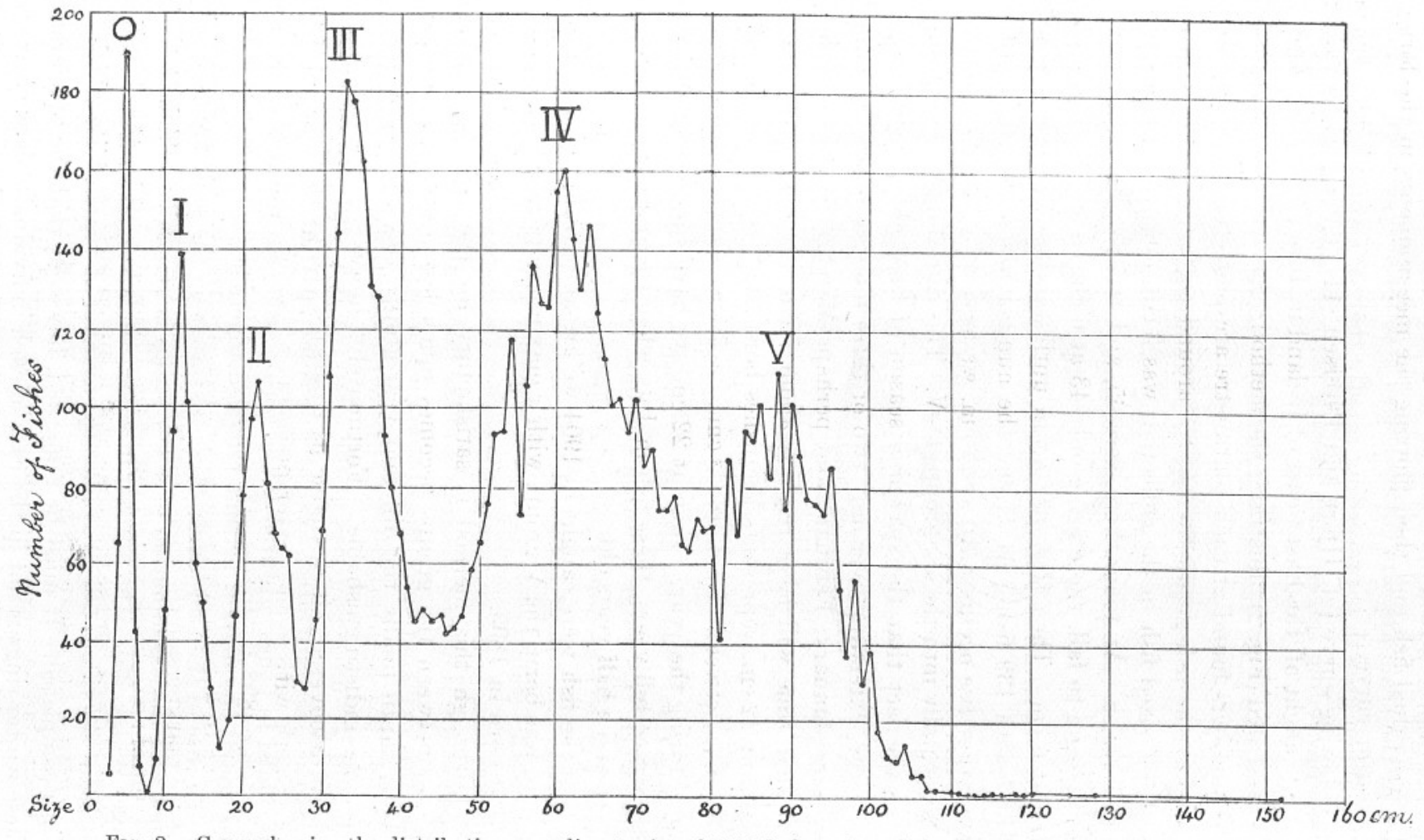

FIG, 2,-Curve showing the distribution according to size of 8046 Cod caught off the East Coast of Iceland, in July, 1904. (After Hjort and Petersen.) 
Fig. 3 is from a drawing of the scale of a coal-fish (Gadus virens). The surface of the scale appears covered with a series of concentric rings or ridges. When growth is proceeding rapidly there is a considerable space between succeeding ridges, when growth becomes slow the ridges crowd

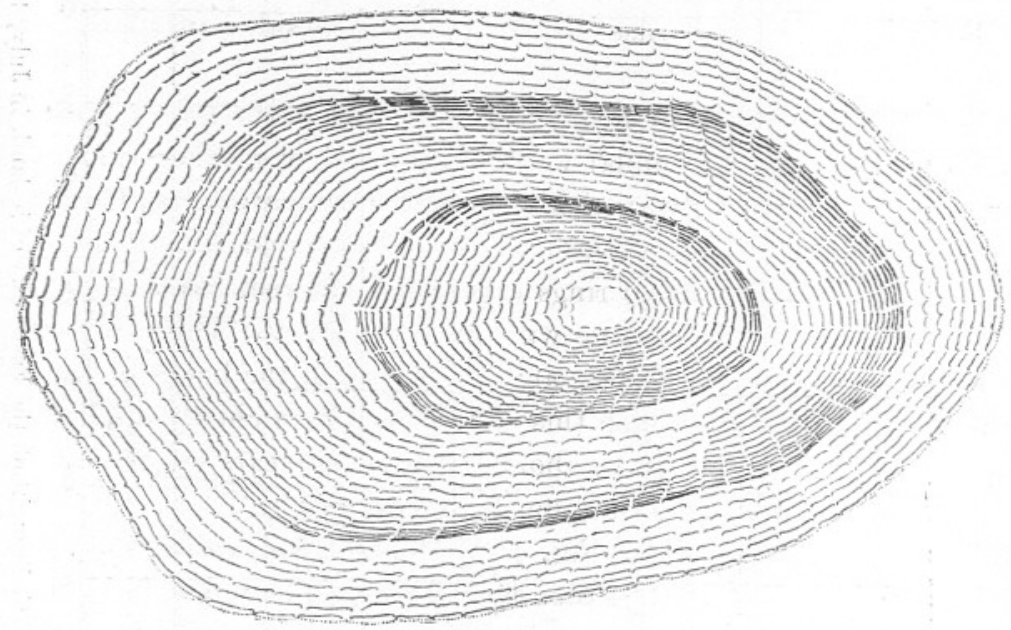

FIG. 3.-Seale of Coal-fish (Gadus virens). (After Damas.)

closely together. But the fish grows most rapidly during the summer months, when the water is warm and food is plentiful, whereas during the winter"growth becomes slower and slower, and even ceases altogether. It is during this winter period of very slow growth that the concentric ridges on the scale become crowded together and give the appearance of a darker ring on the surface of the scale. On the scale figured there are two such winter rings and the growth of the third summer is well advanced.

That this explanation of the appearance presented by the scale is the correct one has been proved by the examination of scales taken from fish caught at different times of the year. A fish captured in summer, such as the one illustrated, has the ridges far apart at the margin of the scale, whilst in fishes captured as the season advances towards winter the ridges round the margin become crowded together.

In the case of the Cod family these markings on the scale are especially distinct and the examination of a few scales is generally sufficient to fix the age (Winge, 25). The number of winter rings formed by the crowding together of the ridges tell us at once the number of years of life which the fish has completed. It must be remarked, however, that the appearance of these winter rings is not in the case of each individual fish as clear and definite as that shown by the scale illustrated, and in a large batch of fish a certain number will be doubtful and the exact age a little uncertain. 
By examining large samples these exceptional instances cease to have any importance, as they are not sufficiently numerous to alter the average values obtained.

The Salmon is one of the fish the age of which is often well shown on the scale, and a good deal of work has been done upon it (Masterman, 18). The Herring is another case which I shall consider in more detail presently.

In certain other fishes, as for example the Plaice, the seales, although they show indications of similar winter rings, are not marked sufficiently clearly to make them easily available for age determination. Fortunately, however, other structures of the fish have been found which show in a very definite way alternating rings expressing different rates of growth, which enable us to estimate age with great accuracy. These structures are (1) the otoliths or ear-stones, and (2) certain of the bones of the fish. In the Plaice, the fish to which this method has been chiefly applied, the age of the younger fishes up to about six or seven years old is best seen on the otolith, that of older ones on the bones.

The otoliths or ear-stones (Fig. 4) are small, oval, calcareous bodies which lie in the cavity of the inner ear. They can be removed easily for

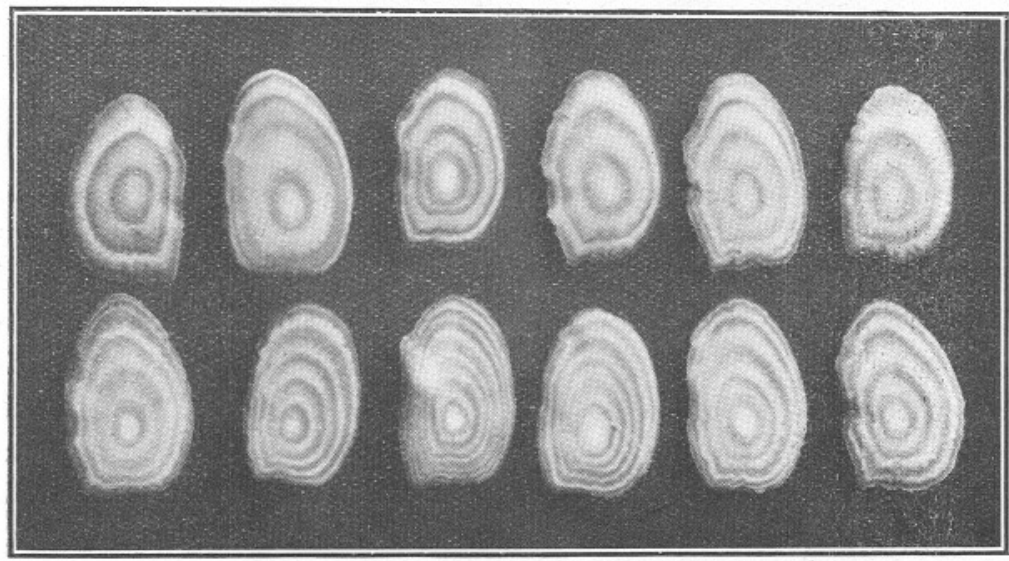

Fig. 4.-Otoliths of mature male Plaice. Upper row-Otoliths of Plaice from the West Bay (English Channel). Lower row-Otoliths of Plaice taken in the southern deep water of the North Sea, near the Gabbard Light Vessel. (After Wallace.)

examination from the dead fish by making a single incision in the head in an appropriate direction, and an inspection with a simple lens generally suffices to make an age determination (cf. Reibisch, 21).

As will be seen from the figure, alternate white and dark rings are seen, when the otolith is examined by reflected light. The white rings are 
formed in spring and early summer, the dark rings in late summer and autumn. During the winter practically no growth of the otolith takes place. The first white ring is formed in the spring following the year of birth, that is when the fish is just one year old, and the total number of white rings will therefore give us the number of years of life which the fish has completed.

As the Plaice gets older, however, the rings at the edges of the otoliths are so crowded together that it becomes impossible to count them. For these older fishes Heincke (9) has shown that an examination of the bones, after special treatment, gives the information required.

It is elear that if we can determine the age of individual fishes, and if we do this on sufficiently large samples, we at once obtain some information as to their rate of growth, for if, say, the average size of the two-yearold Plaice in a particular locality is $20 \mathrm{~cm}$. and the average size of the three-year-olds is $25 \mathrm{~cm}$. we shall not be far wrong in concluding that a Plaice of $20 \mathrm{~cm}$. will grow about $5 \mathrm{~cm}$. during the next year of its life. This conclusion, however, assumes that the conditions of growth are the same each year, and from information now available we know that this is not always true, but that some years are more favourable for growth than others. Growth in different localities, also, even though they may not be very distant from each other, may differ greatly. What we can obtain by the use of the methods already described, if the observations are repeated for a number of years, is the average rate of growth for each year of age.

There are, however, other methods by means of which we can get an idea of the actual rate of growth in a particular area at a particular time. The one which has been most used and has yielded the most reliable results is the method of marking experiments. In these experiments a healthy fish is measured soon after being caught and a small metal label is attached to it, generally at the base of the dorsal fin. The label is numbered and the fish is returned to the sea. When it is subsequently caught again by the fishermen it can be identified by its number and measured a second time. The actual amount of growth will then be known. A great many experiments of this kind have been made on both Plaice and Cod, and large numbers of the fish have been caught and returned by the fishermen to the various laboratories. Even these experiments, however, which were carried out primarily to give information as to the migrations of the fish, are subject to at least one possibility of error, owing to the fact that the future growth of a fish may be considerably retarded by any slight injury it may have sustained when it was first caught. This source of error has to some extent been overcome by keeping the fish in tanks of running sea-water for some time before 
they are measured and marked, and only using such fish as appear to be quite uninjured and full of vigour.

We must now pass on to consider some of the conclusions which have resulted from the use of these methods of investigating age and growth rate. In the case of the Plaice, the researches of Dr. Wallace, which were carried out at the Lowestoft Laboratory of the Marine Biological Association, are amongst the most important. The method he employed was the study of the otoliths, his results being based on a total of 20,000 fish, each of which was measured and its age determined. In addition to this Wallace makes use of the records of the otoliths of another 20,000 measured Plaice collected by the Board of Agriculture and Fisheries (24). These numbers will give some idea of the extent of the investigations which have been made.

The following table embodies the result of the analysis as regards age of two series of samples of Plaice trawled by Wallace along a line nearly at right angles to the Dutch coast, from Texel to the Leman Banks, commencing about three miles from the shore and running out some eighty or ninety miles into the North Sea. The samples were taken in May and September, 1905. (Wallace, 23, Rep. II, Pt. I, p. 26.)

1. Males.

The I group averaged $9.4 \mathrm{~cm}$. in May and $14.9 \mathrm{~cm}$. in Sept.

\begin{tabular}{|c|c|c|c|c|}
\hline II & , & $16 \cdot 2 \mathrm{~cm}$. & , & $19 \cdot 9 \mathrm{~cm}$ \\
\hline III & , & $22 \cdot 2 \mathrm{~cm}$ & , & $25.4 \mathrm{~cm}$ \\
\hline IV & ,", & $27 \cdot 2 \mathrm{~cm}$ & , & $29 \cdot 3 \mathrm{~cm}$ \\
\hline V & , & $31.6 \mathrm{~cm}$ & , & $33.7 \mathrm{~cm}$. \\
\hline VI & ,. & $34.8 \mathrm{~cm}$. & , & $34.5 \mathrm{~cm}$. \\
\hline
\end{tabular}

2. Females.

The I group averaged $10 \cdot 3 \mathrm{~cm}$. in May and $15 \cdot 2 \mathrm{~cm}$. in Sept.

\begin{tabular}{|c|c|c|c|c|}
\hline II & , & $16.8 \mathrm{~cm}$. & , & $20.9 \mathrm{~cm}$. \\
\hline III & , & $23 \cdot 6 \mathrm{~cm}$. & , & $25.8 \mathrm{~cm}$ \\
\hline IV & , & $28.3 \mathrm{~cm}$. & , & $30.9 \mathrm{~cm}$. \\
\hline V & , & $34 \cdot 3 \mathrm{~cm}$. & , & $37.7 \mathrm{~cm}$. \\
\hline VI & ., & $38.5 \mathrm{~cm}$. & & $41.3 \mathrm{~cm}$. \\
\hline
\end{tabular}

[A number of diagrams were also shown illustrating Wallace's results.]

The samples of fish from which these figures were derived were taken, as already stated, upon a line extending from the Dutch coast seawards to a distance of eighty or ninety miles. Wallace was the first to point out that if we are to obtain really accurate values for the average size of the Plaice belonging to any particular age-group in a given locality, we can only do so by collecting samples uniformly in this way at different 
distances from the shore. In order to make it clear why this is so, it will be necessary to give a short account of the distribution of the Plaice according to size, and for this purpose we will consider its distribution in the North Sea.

When we were dealing with the larval stages of the Plaice, you will recollect that we left the earliest bottom stages inhabiting the margins of the sandy shores in quite shallow water. During the first year of their life the young Plaice remain close to the shore in depths under ten fathoms. As they grow larger they move further and further seawards

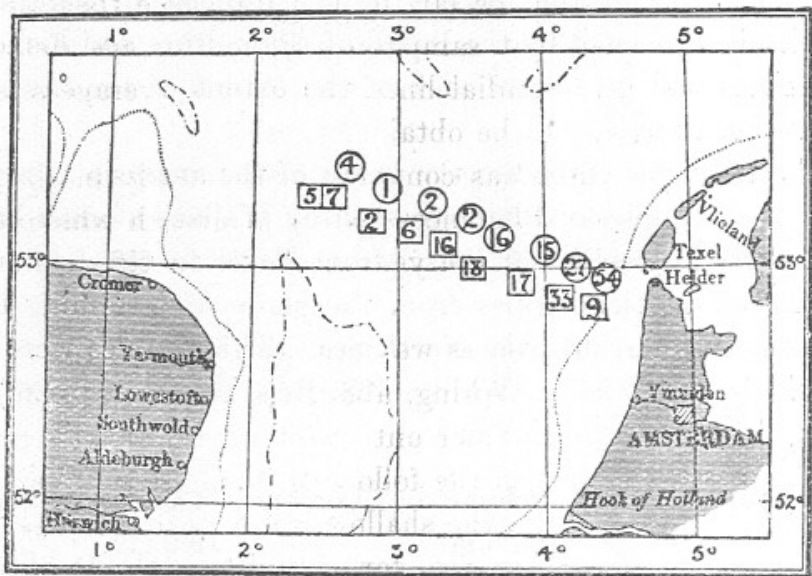

Fig. 5. - Plaice. Catch per hour of the III Group. (After Wallace.)

$\mathrm{O}=$ May, 1906 (Covered Beam Trawl).

$\square=$ September, 1905 (Otter Trawl).

away from these nursery grounds, and in the North Sea it may be taken as a general rule that the average size of the Plaice becomes larger the further out into the open sea we get.

This is well illustrated by the charts published by Garstang (8) showing the distribution of Plaice in the North Sea according to average size.

This seaward movement, it is important to note, depends upon the size of the fish rather than upon their age, so that the larger individuals of any year class are found further out to sea than the smaller ones. If we now look at the next Chart by Wallace (Fig. 5), which illustrates the catch per hour of Plaice of the III Group, that is fish between three and four years old, on the line running out from the Dutch coast-from Texel to the Leman Bank-we shall see that this group is taken along the whole line. It is most abundant near the coast, where the average size of the fish is small, and the numbers captured gradually diminish as we move seawards, the size of the fish at the same time becoming larger. The chart also shows that between May (represented by the circles) and 
September (the squares) there has been a distinct shifting of the group of fish seawards as they have grown larger.

It will be clear, therefore, that if the fish are distributed in this way according to size, we must take uniform samples all along the line in order to obtain the true average of those belonging to any age-group. If, for instance, in the case of this III Group we took samples only near the coast we should miss all the larger fish belonging to the group, whereas if we took samples only at the seaward end of the line we should miss all the small ones. In the latter ease our average would be far too high, in the former case it would be far too low. Wallace therefore is quite justified in maintaining that samples of Plaice for age determination must be taken upon such radial lines, if accurate average sizes for the different years of age are to be obtained.

One of the points which has come out most clearly in the course of these studies is the great differences in rate of growth which are found, firstly at different seasons of the year, secondly in different years, and thirdly in different localities.

As regards seasonal differences we may say that in the North Sea the year's growth begins in the spring, about the month of April ; it goes on vigorously during the summer until September, slows down in October, and from that time until the following April there is practically no growth at all, at any rate in the shallow water near the coasts. In the central portions of the North Sea, for example on the Dogger Bank, a certain amount of growth does seem to take place in the winter.

The evidence for differences in the rate of growth of Plaice in different years is chiefly based on the work of the Danish naturalist Johansen (14), who has studied the question by means of marking experiments carried out off the North Sea coast of Denmark. Thus the average annual growth for specimens of 20 to $29 \mathrm{~cm}$. liberated in the Horn Reef area in 1903 was only about $4 \mathrm{~cm}$., whilst in 1904, 1905, 1906 and 1907 it was from 6 to $7.5 \mathrm{~cm}$. In this connection Johansen notes the interesting fact that in 1903, when the growth was abnormally low, there was an unusually rich stock of under-sized fish on the Horn Reef grounds, which suggests that the rate of growth may depend, amongst other things, upon the density of the Plaice population (Johansen, 14, III, p. 37).

It is possible, therefore, that a certain amount of fishing on grounds overcrowded with young fish may tend to increase the rate of growth of the fish that remain.

That the rate of growth of Plaice differs widely in different localities may be inferred from the fact that the average length of the different age-groups is different in different areas, provided always that the samples on which the figures are based are adequately distributed or at least 
properly comparable. Thus Wallace's samples show that Plaice of the II Group in August, that is fish two and a half years old, average $6 \mathrm{~cm}$. longer in Tor Bay on the South Devon Coast than those in deeper water on the Leman Banks in the North Sea, and $11 \mathrm{~cm}$. longer than those from the shallow water off the coast of Lincolnshire, the Devon fish being thus from one to two full years ahead of those from the North Sea.

This rapid growth of the Devon fish is clearly reflected in the structure of the otolith, as will be seen from Fig. 4. The broad white rings are in marked contrast to the narrow rings of the North Sea fish (Wallace, 23, Rep. III, p. 142A, Figs. 6 and 7).

The following table (p. 415) summarizes Wallace's results as to the average size of Plaice of the different age-groups in different localities.

From this table it is possible also to compare the difference in rate of growth of males and females. It will be seen that on the whole females grow more rapidly than males, and that this difference tends to increase as the fish grow older.

The great differences which may occur in the rate of growth of Plaice on different grounds are strikingly shown by the results of the transplantation experiments carried out by Garstang and Borley in the North Sea [Garstang (7), Borley (2), Lee and Atkinson (17)]. Small Plaice

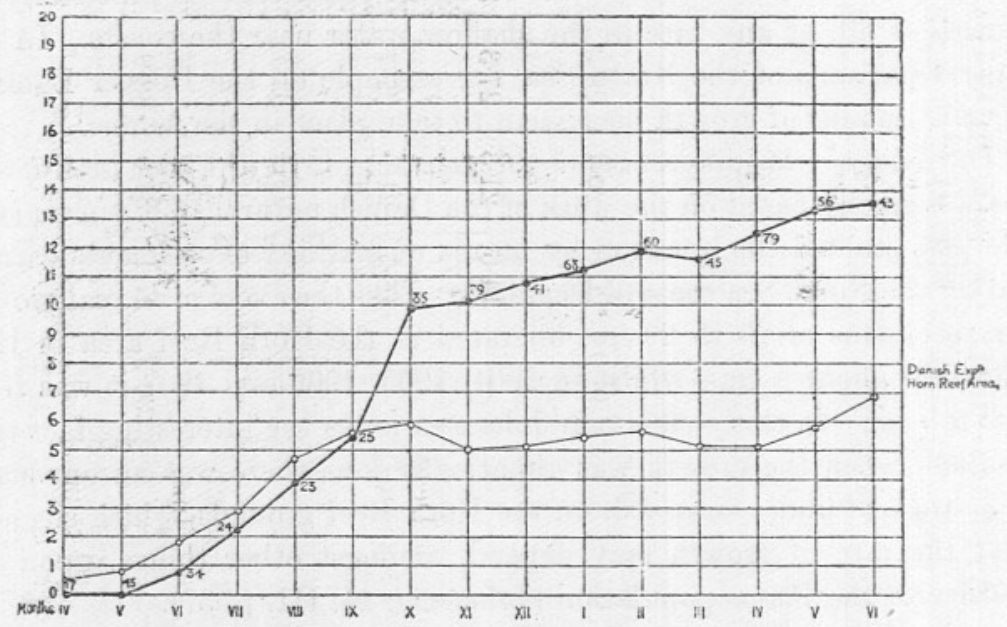

FIG. 6.-Showing growth of fish transplanted to the Dogger Bank in the combined experiments of the years 1904-8 compared with that shown by the Danish marking experiments in the Horn Reef area in the years 1903-5. (After Borley.)

caught on the shallow young-fish nurseries off the Danish and Dutch coasts were carried in sea-water tanks to the Dogger Bank, which lies in the middle of the North Sea. They were then measured, marked with 
AVERAGE SIZES OF THE PRINCIPAL AGE GROUPS OF PLAICE FROM DIFFERENT FISHING GROUNDS.

From Wallace [23], Report III, Tables 11 to 16, pp. 136-141. Length in centimetres.

\begin{tabular}{|c|c|c|c|c|c|c|c|c|c|c|c|c|c|}
\hline \multirow{2}{*}{ Age Groups. } & \multicolumn{6}{|c|}{ MaLes. } & \multicolumn{7}{|c|}{ Females. } \\
\hline & I & II & III & IV & V & VI & I & II & III & IV & V & VI & VII \\
\hline $\begin{array}{l}\text { Texel to Leman Banks. Sep- } \\
\text { tember, 1905. } 7-17 \mathrm{fms} \text {. }\end{array}$ & 14.9 & $20 \cdot 0$ & $25 \cdot 4$ & $29 \cdot 3$ & - & - & $15 \cdot 1$ & $20 \cdot 9$ & $25 \cdot 8$ & $30 \cdot 9$ & & - & $\cdots$ \\
\hline $\begin{array}{l}\text { Texel to Leman Banks. May, } \\
\text { 1906. 13-17 fms. }\end{array}$ & - & $14 \cdot 6$ & $21 \cdot 3$ & $27 \cdot 3$ & $30 \cdot 9$ & - & - & $14 \cdot 9$ & $22 \cdot 5$ & $28 \cdot 8$ & $32 \cdot 9$ & - & - \\
\hline $\begin{array}{l}\text { Scheveningen and Southern Deep } \\
\text { Water. May, 1906. 12-23 fms. }\end{array}$ & - & $16 \cdot 5$ & $21 \cdot 9$ & $27 \cdot 7$ & $31 \cdot 1$ & - & - & $17 \cdot 7$ & $22 \cdot 7$ & $29 \cdot 1$ & $32 \cdot 4$ & - & - \\
\hline $\begin{array}{l}\text { South Dogger and Flamboro' Off. } \\
\text { Winter (Oct.-March) }\end{array}$ & - & - & $29 \cdot 1$ & $34 \cdot 1$ & $37 \cdot 0$ & $38 \cdot 1$ & $\rightarrow$ & - & $30 \cdot 4$ & $36 \cdot 6$ & $41 \cdot 0$ & $44 \cdot 1$ & $47 \cdot 5$ \\
\hline $\begin{array}{l}\text { Great West Bay (English Channel). } \\
\text { Winter (Nov.-Feb.). } 3-7 \text { fms., } \\
17-30 \text { fms. }\end{array}$ & $20 \cdot 3$ & $27 \cdot 1$ & $31 \cdot 0$ & $32 \cdot 9$ & - & - & $20 \cdot 4$ & $28 \cdot 3$ & $31 \cdot 8$ & $35 \cdot 5$ & - & - & - \\
\hline $\begin{array}{l}\text { Tor Bay and Start Bay. August, } \\
\text { 1909. 3-8 fms. }\end{array}$ & $18 \cdot 3$ & $27 \cdot 9$ & $31 \cdot 3$ & - & - & - & $18 \cdot 4$ & $27 \cdot 7$ & 33.5 & $37 \cdot 4$ & $41 \cdot 3$ & - & - \\
\hline
\end{tabular}


numbered labels and liberated. The transplantation was carried out in May, and during the following year large numbers of the marked fishes were returned by the fishermen. The amount of growth shown by the following autumn and winter was very remarkable. Small, under-sized fish of little or no market value had become fine Plaice, of good size and in excellent condition. The preceding diagram (Fig. 6) shows the growth of these transplanted fish, compared with the growth of fish of the same size which had remained on the inshore grounds. Taking the figures for, say, the following January, whereas the average length of the transplanted fish was $11 \mathrm{~cm}$. the size of those left on the Horn Reef ground was about $5.5 \mathrm{~cm}$.

If instead of considering the length of the fish we take the percentage increase of weight the result is even more striking. Whereas by the following spring the fish that remained on the Danish Horn Reef ground had increased in weight by 100 per cent., that is to say, had doubled their weight, those put out on the Dogger had increased their weight by 400 per cent., that is to say, they were five times as heavy as they were originally.

Since well-grown Plaice command a much higher price per lb. than small ones this increase of weight means that the value has increased to perhaps seven times the original value.

These results of investigations on the age of Plaice and their rate of growth have several important practical aspects, apart from the suggestion of a direct improvement of the fishery by the transplantation of young fish from crowded nursery grounds to rich feeding grounds such as the Dogger Bank, where the rate of growth is much more rapid. It would seem that the most profitable fishery would result from concentrating the fishing as much as possible on Plaice of the Age Groups IV, V and VI, that is to say, on fish in the fifth, sixth and seventh years of their life. Before this they are small, but capable of rapid growth and rapid increase in value. After the seventh year the growth gets slower, and as long as a sufficient supply of mature fish is allowed to remain to ensure an adequate amount of spawn for the perpetuation of the race, it would appear that from a commercial point of view it is of greater advantage to put the seven year olds on the market rather than to allow them to remain in the sea. They would increase in value very little compared with the amount of nourishment they would consume, whilst when they are removed the food they would have eaten becomes available for the younger fishes, which grow in size and value at a much more rapid rate.

In this connection the age at which the majority of Plaice mature for the first time is important. According to Wallace (24, p, 40) for female Plaice this "age of first maturity" in the Southern North Sea is five 
years, in the middle North Sea six years, and further north seven years. In the English Channel, on the other hand, the bulk of the females reach maturity at four years of age. The average age for the males may be a year earlier than for the females.

We have now perhaps devoted sufficient attention to the Plaice, and will pass on to consider certain investigations into the age of the Herring, which bring out very clearly another application of a knowledge of the age of fishes, which may have an important practical bearing. These investigations we owe especially to the energy and enterprise of Norwegian naturalists under the leadership of Dr. Johan Hjort.

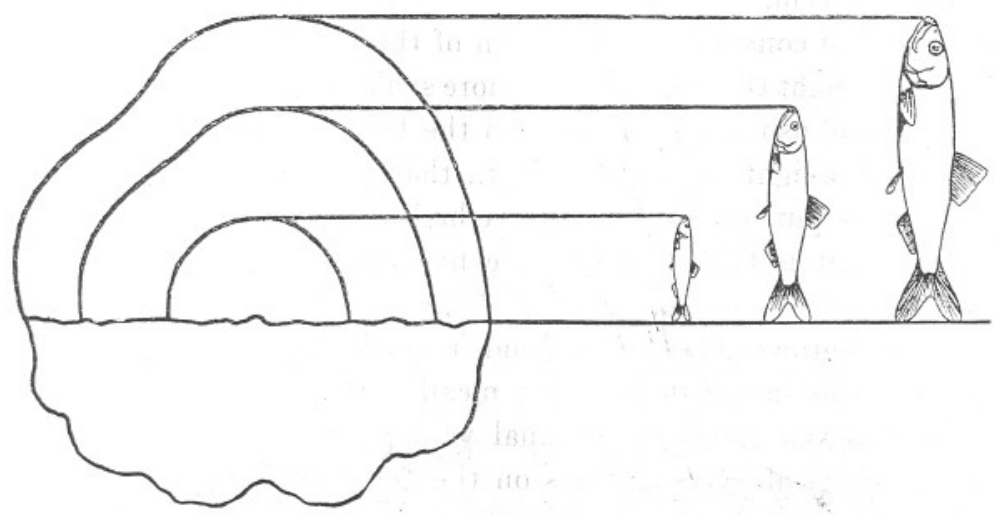

FIG. 7.-Growth zones of herring scales compared with size of fish.

(After Hjort.)

As with most marine fishes, the growth of the Herring comes practically to a standstill during the winter. This winter rest is clearly indicated by a ring-like mark on the surface of the scale, these rings being often very definite and precise.

That each ring really does represent the cessation of growth during the winter has been proved by Lea, by examining samples of Herrings month by month during the year (12), in the same way as was done by Wallace with the otoliths of the Plaice. It was possible to follow the band of summer growth becoming wider and wider, until as winter came on it ceased, and the darker ring was found at the margin of the scales. This being so it is obvious that an examination of the scale can tell us a good deal more about a fish's history than merely its age. We can indeed infer the length of the fish at the end of any particular year of its life, for it has been possible to show that the length of the fish is always proportional to the length of a particular scale. If, therefore, we magnify the scale until its total length from the median transverse line to the edge is equal to the length of the fish, the distance from this line to each of the winter 
rings will be the length which the fish had at the time the ring was formed. This will be clear from the diagram Fig. 7 .

Fig. 8 illustrates the composition of three samples of Norwegian Spring Herring taken in March, 1907, and analysed by Dahl (3), by an examination of the scales, into age groups. It will be seen that the majority of

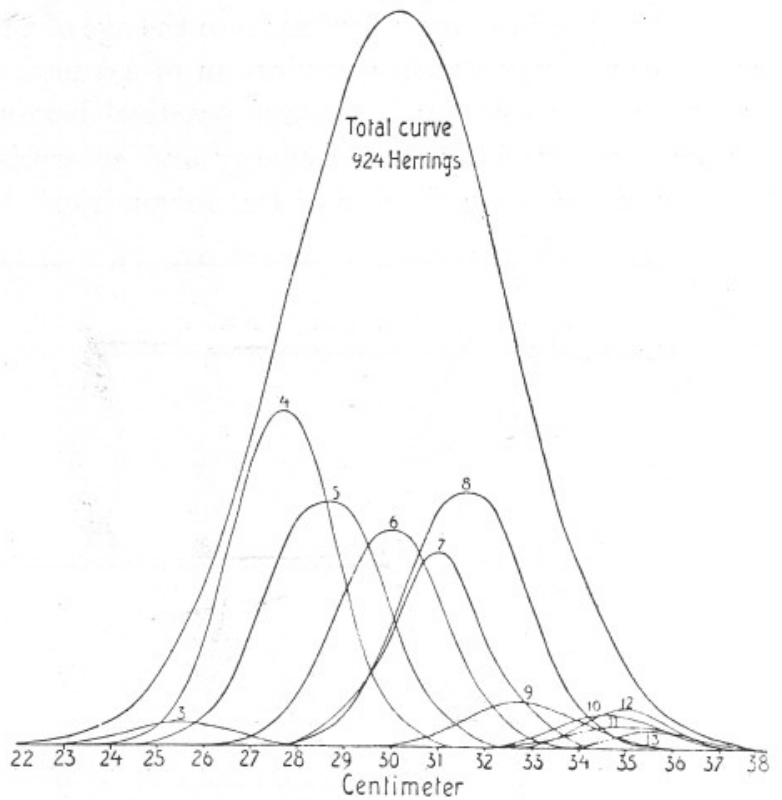

Fic. 8.-Analysis of three samples of Norwegian Spring Herring taken in March, 1907, into age groups. (After Dahl.)

the fish belong to the IV, V, VI, VII and VIII year-classes, the bestrepresented class being IV. The position of the apex of each curve gives us the size of fish most frequently found in each age group.

Samples of Norwegian Spring Herring have been examined in this way every year since 1907 and the results obtained are given in the following table (p. 419), the number of fish belonging to each year-class being expressed as a percentage of the whole sample (Hjort, 12, p. 219, Table I).

An examination of the figures in this table reveals a very remarkable fact. If we commence with the year 1908 , we see that 34.8 per cent. of the fish belong to the year-class IV, that is to say, they are fish which were born in the year 1904. We see further that no other year-class is nearly as well represented, the next in order being the IX year-class, of which the sample contains $14 \cdot 4$ per cent. Now look at the percentages for the year 1909; the best represented class is the $\mathrm{V}$ year-class, with $43 \cdot 7$ per cent. But in 1909 the V year-class is composed of fish born in 
AGE OF NORWEGIAN SPRING HERRING IN THE YEARS 1907-1914.

THE REPRESENTATION OF EACH YEAR-CLASS IS GIVEN IN PERCENTAGES.

\begin{tabular}{|c|c|c|c|c|c|c|c|c|c|c|c|c|c|c|c|c|c|c|c|}
\hline & YEAR & -CLAA & SES & & 3 & 4 & 5 & 6 & 7 & 8 & 9 & 10 & 11 & 12 & 13 & 14 & 15 & 16 & 17 \\
\hline 1907 & . & . & . & . & $1 \cdot 6$ & $22 \cdot 2$ & 18.5 & $14 \cdot 8$ & $12 \cdot 6$ & $19 \cdot 4$ & $3 \cdot 4$ & $2 \cdot 3$ & $1 \cdot 7$ & $2 \cdot 2$ & $0 \cdot 9$ & $0 \cdot 5$ & - & - & - \\
\hline 1908 & . & . & . & . & - & $34 \cdot 8$ & $12 \cdot 2$ & $11 \cdot 6$ & $11 \cdot 1$ & $8 \cdot 5$ & $14 \cdot 4$ & $1 \cdot 9$ & $1 \cdot 1$ & $1 \cdot 5$ & 1.5 & $0 \cdot 6$ & $0 \cdot 3$ & $0 \cdot 1$ & $0 \cdot 1$ \\
\hline 1909 & . & . & . & . & - & $0 \cdot 4$ & $43^{19}$ & $11 \cdot 9$ & $4 \cdot 1$ & $4 \cdot 8$ & $6 \cdot 7$ & $17 \cdot 6$ & $3 \cdot 3$ & $2 \cdot 6$ & $1 \cdot 6$ & $2 \cdot 3$ & $0 \cdot 4$ & $0 \cdot 2$ & $0 \cdot 4$ \\
\hline 1910 & . & . & . & . & - & $1 \cdot 2$ & $9 \cdot 9$ & $\operatorname{ryg} \cdot 3$ & $6 \cdot 7$ & $1 \cdot 0$ & $0 \cdot 4$ & $1 \cdot 1$ & $2 \cdot 0$ & - & - & - & - & - & - \\
\hline 1911 & . & . & . & . & - & $0 \cdot 6$ & $4 \cdot 1$ & $17 \cdot 3$ & 190.0 & $5 \cdot 5$ & $1 \cdot 5$ & $0 \cdot 6$ & 0.5 & $0 \cdot 1$ & - & - & - & - & - \\
\hline 1912 & . & . & . & . & - & $1 \cdot 6$ & $3 \cdot 1$ & $3 \cdot 9$ & $14 \cdot 5$ & $64 \cdot 3$ & $6 \cdot 4$ & $1 \cdot 6$ & $1 \cdot 2$ & $1 \cdot 2$ & 1.5 & $0 \cdot 6$ & $0 \cdot 1$ & - & $0 \cdot 1$ \\
\hline 1913 & . & . & . & . & $0 \cdot 1$ & 0.7 & $2 \cdot 2$ & $3 \cdot 4$ & $4 \cdot 8$ & $13 \cdot 3$ & $64 \cdot 7$ & $5 \cdot 1$ & $1 \cdot 2$ & $1 \cdot 2$ & 0.5 & $0 \cdot 2$ & $0 \cdot 2$ & - & - \\
\hline 1914 & . & . & . & . & - & 0.6 & $3 \cdot 3$ & $6 \cdot 9$ & $5 \cdot 2$ & $7 \cdot 2$ & $13 \cdot 9$ & $54 \cdot 3$ & $5 \cdot 0$ & $1 \cdot 5$ & $1 \cdot 2$ & 0.4 & 0.5 & - & - \\
\hline
\end{tabular}


1904. In 1910 the VI year-class, with $77 \cdot 3$ per cent., completely dominates the others; still the fish born in 1904. In 1911 the VII year-class, in 1912 the VIII year-class, and in 1913 the IX year-class still form from 64 to 70 per cent. of the whole population, the fish in each case being those born in 1904. In 1914 these fish still form 54.3 per cent. of the whole. Thus it will be seen that for six or seven years this one year-class of 1904 dominates the fishery. If we look at the figures still more closely we shall see further evidence that a particular year-class may be of special importance over a series of years. In 1910 the fish of year-class $\mathrm{V}$ formed $9 \cdot 9$ per cent. of the sample, being the second largest of the year-classes present. These fish were born in 1905. In 1911 these 1905

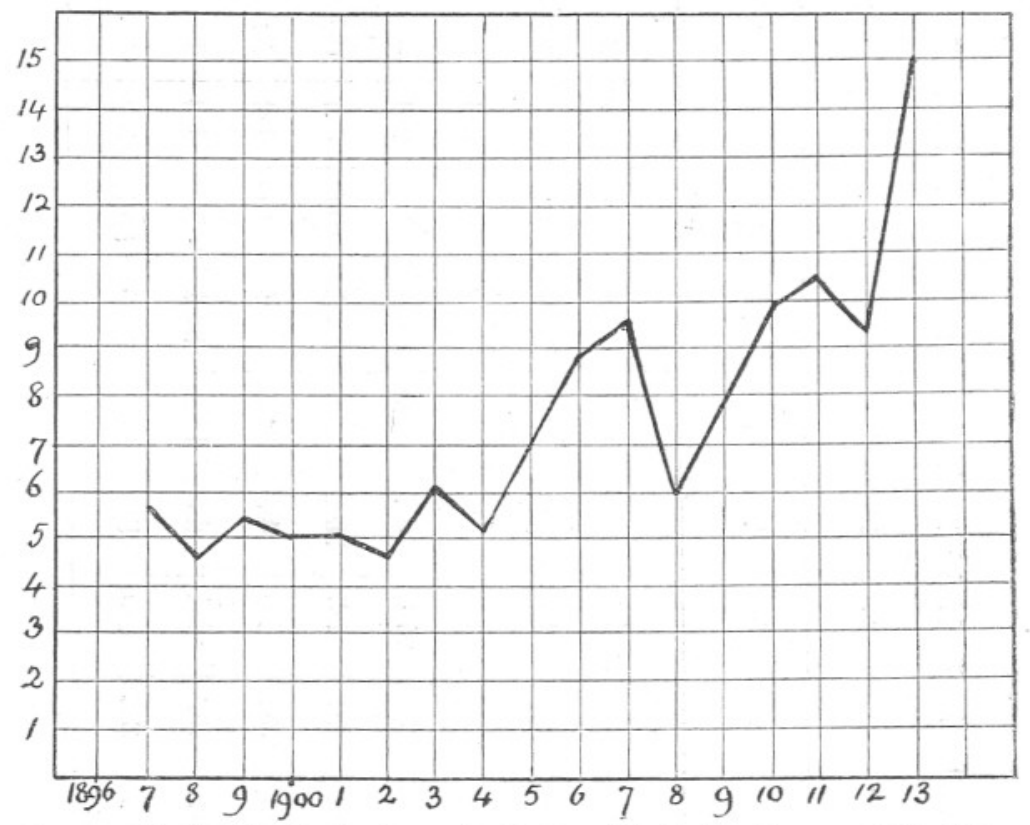

Fis. 9.-Yield of the Norwegian spring herring fisheries for the years 1896-1913. $15=1,500,000$ hectolitres. 1 hectolitre $=22$ gallons. (After Hjort.)

born fish belong to the VI class, and again they are second in importance with $17 \cdot 3$ per cent. The class occupies the same position in 1912 and in 1913 , when the fish are seven and eight years old respectively. Similarly the fish born in 1899 form the VIII group in 1907, the IX group in 1908, and the $\mathrm{X}$ group in 1909, the group in each case being present in considerably greater numbers than fish of the adjacent groups.

The herring fishery is one which is subject to very great fluctuation from year to year, and to those who have watched the fishery for many years it is a well-recognized fact that bad and good years often run in 
series. After a number of poor or average years the fishing begins to improve and remains successful for three or four years in succession. In the case of the Norwegian Spring Herring fishery the years from 1909 to 1913, when the fish of the 1904 class predominated, were exceptionally good years, with a very high yield, the year 1913 especially being the best fishery during the whole period from 1896 to 1913 (Fig. 9).

We are furnished, therefore, with what appears to be a distinct step in advance in our attempts to find a rational explanation of the fluctuations in the fisheries. A season occurs in which the conditions are exceptionally favourable for the production of young fish, either owing to an exceptional supply of nourishment upon which the larvæ and fry can feed, or to the absence of enemies, or to some other cause which at present has not been traced. As these fish grow up they year by year come to form a more important factor in the yield of the fishery and the abundance of fish caught increases. In the case we have considered the Herrings born in 1904 dominated and rendered fruitful the fishing of the six years from 1909 to 1914. How much longer their influence will be felt remains to be seen.

What appears to be an exactly parallel case occurred in the North Sea Haddock fishery, and curiously enough it was again fish of the year 1904 that were exceptionally abundant. The young fish of 1904 began to show in the catches in 1905, and in 1906 they were present in extraordinary numbers (Helland-Hansen, 10, p. 33). Although the case has not been worked out in the same detail as for the Herring, the statistics show an exceptional quantity of medium-sized Haddock in 1907, and of large Haddock from 1907 to 1910. This is just what we should expect from the gradual growth of the fish born in 1904, which were so exceptionally abundant in 1906.

For the Plaice also it has been shown that the abundance of the young brood on the nursery grounds varies greatly from year to year (Johansen, 14, Pts. III and VI), and there is little doubt that the same sequence of events occurs in the case of this fish, though it has not up to the present been followed in detail.

These investigations, then, seem to give us one of the keys necessary for a proper understanding of much in relation to the fluctuations of the fisheries which was previously difficult to understand. Moreover, they offer a prospect of enabling us to predict the probable course of the fishery some years ahead, for when the exceptional abundance of the young fish of any year has been discovered, we shall be able to say, from a knowledge of the growth-rate of the fish, in how many years these fish will reach marketable size and if all goes well with them give rise to an abundant fishery. Information of this kind, intelligently applied, ought 
to be of some use to the practical fisherman. To those whose duty it is to study the fisheries from the point of view of legislative or administrative control, it is of course of the very greatest importance.

As was explained at the beginning of this address, I have attempted to lay before you some account of one single branch of fishery research, and as I have proceeded you will no doubt have felt that a subject which at first sight seemed fairly straightforward and simple developed quite unexpected complexity, and yielded in the end quite unexpected results. This is indeed only the common experience of those who break new ground or explore new territories in any branch of knowledge whatever, but in the case of marine research the difficulties are perhaps exceptionally great and the calls on the patience and perseverance of the investigator are almost unlimited. But those who have been most intimately associated with this research and have followed it in greatest detail are the most convinced of its promise of fruitful result. We must look to the growing intelligence of the larger public, grown wiser, may we hope, in the stern school of war, for that appreciation which will enable it to be continued with the means and resources which its difficulties demand.

\section{LIST OF LITERATURE.}

1. Apstern. Die Bestimmung des Alters pelagisch lebender Fischeier. Mitt. Deutsch. Seefisch. Ver. XXV. 1909, p. 364.

2. Borley, J. O. Report on the Experimental Transplantation of Plaice to the Dogger Bank. Mar. Biol. Assocn. Internat. Invest. Report. IV. [Cd. 6125.] 1912.

3. DAHL, K. The Scales of the Herring as a means of determining Age, Growth and Migration. Rep. Norw. Fish. and Marine Invest. Vol. II. No. 6. 1907.

4. Damas, D. Contribution à la Biologie des Gadides. Conseil Internat. pour l'Explor. de la Mer. Rapp. et Proc. Verb. X. 1909.

5. Dannevig, H. The Influence of Temperature on the Development of the Eggs of Fishes. 13th Ann. Rep. Fish. Board Scotland. Pt. III, p. 147. 1895.

6. Fabre-Domergue et Biḱtrix. Développement de la Sole. Paris. 1905.

7. Garstang, W. Experiments in the Transplantation of small Plaice to the Dogger Bank. Mar. Biol. Assocn. Internat. Invest. Report. I. [Cd. 2670.] 1905 . 
8. Garstang, W. The Distribution of the Plaice in the North Sea, Skagerak and Kattegat, according to Size, Age and Frequency. Cons. Internat. p. l'Explor. de la Mer. Rapp. et Proc. Verb. XI. 1909.

9. Heincke, Fr. Bericht über die Untersuchungen der Biologischen Anstalt auf Helgoland zur Naturgeschichte der Nutzfische. Beteil. Deutschl. Internat. Meeresforsch. IV-V. 1908.

10. Helland-Hansen, B. Statistical Research into the Biology of the Haddock and Cod in the North Sea. Conseil Internat. pour l'Explor. de la Mer. Rapp. et Proc. Verb. X. 1909.

11. Huort, J., and Petersen, C. G. J. Short Review of the results of the International Fisheries Investigations. Conseil Internat. pour l'Exploration de la Mer. Rapp. et Proc. Verb. III. Appendix G. 1905.

12. Hлorт, J. Fluctuations in the Great Fisheries of Northern Europe viewed in the light of Biological Research. Cons. Internat. pour l'Explor. de la Mer. Rapp. et Proc. Verb. Vol. XX. 1914. (Contains on pp. 10-13 a list of the principal memoirs on the Age of the Herring.)

13. Hoffbauer, C. Die Altersbestimmung des Karpfens an seiner Schuppe. Allgemeine Fisch. Zeit. 1898. No. 19.

14. Johansen, A. C. Contributions to the Biology of the Plaice. Medd. Komm. Havunters. Fisk. Pt. I in Bil. I, No. 2, 1905 ; Pt. II in Bd. II, No. 5, 1907 ; Pt. III in Bd. III, No. 4, 1908 ; Pt. IV in Bd. III, No. 5, 1908; Pt. V in Bd. IV, No. 1, 1912 ; Pt. VI, Bd. IV, No. 4, 1913 ; Pt. VII, Bd. IV, No. 9, 1915.

15. Johansen, A. C. Bericht über die dänischen Untersuchungen über die Schollenfischerei. Med. Komm. Havunters. Fisk. Bd. III, 8. 1910.

16. Johansen and Krogh. The Influence of Temperature and certain other Factors upon the Rate of Development of the Eggs of Fishes. Cons. Internat. p. l'Expl. de la Mer. Publ. de Circons. No. 68. 1914.

17. Lee, R. M., and Atkinson, G. T. Report on Plaice Transplantation Experiments to various Fishing Grounds in the North Sea. Mar. Biol. Assocn. Internat. Invest. Report. IV. [Cd. 6125.] 1912.

18. Masterman, A. T. Report on Investigations upon the Salmon with special reference to Age-determination by Study of Scales. Bd. of Agric. and Fisheries. Fishery Investigations. Ser. I. Vol. I. 1913.

19. Petersen, C. G. J. On the Biology of our Flatfishes. Report Danish Biol. Sta. IV. 1893 [1894]. 
20. Redeke, H. C. Bericht über die hollandische Schollenfischerei und über die Naturgeschichte der Scholle in der südlichen Nordsee. Verhand. Rijks. Instit. v. onderzoek der Zee. II, 5. 1909.

21. Reinisch, J. Eizahl bei $P l$. platessa und die Altersbestimmung dieser Form aus den Otolithen. Wissensch. Meeresunters. N.F. Bd. IV. Kiel. 1899.

22. Thompson, Stuart. The Periodic Growth of Scales in Gadidæ as an index of Age. Journ. Mar. Biol. Assoc. VI, 1902, and VII, 1904.

23. Wallace, W. Mar. Biol. Assoc. International Investigations.

Report I (1902-03) [Publ. 1905];

Report II (1904-05) Pt. I [Publ. 1907];

Report II (1904-05) Pt. II [Publ. 1909];

Report III (1906-08) [Publ. 1911].

24. Waltace, W. Report on the Age, Growth and Sexual Maturity of the Plaice in certain parts of the North Sea. Bd. of Agric. and Fisheries. Fishery Investigations. Ser. II. Vol. II. No. 2. 1915.

25. Winge, O. On the Value of the Rings in the Scales of the Cod as a means of Age Determination. Illustrated by Marking Experiments. Medd. Komm. Havunders. Fisk. IV. No. 8. 1915.

For further references to the literature of the subject see :

DAHL, K. The Assessment of Age and Growth in Fish. Internat. Rev. Hydrobiol. and Hydrogr. II, 1909, p. 758.

\section{British and Metric Measures.}

To convert millimetres to inches multiply by $\cdot 039$.

centimetres , , , , 39 .

The following equivalents will be useful in reading this paper :-

$$
\begin{aligned}
& 1 \mathrm{~mm} .=\frac{1}{25} \text { inch. } \\
& 3,=\frac{1}{10}, \text {, } \\
& 6,,=\frac{1}{4}, \\
& 13, y=\frac{1}{2}, \\
& 1 \mathrm{~cm} .=\frac{2}{5} \text { inch. } \\
& 2 \cdot 5,,=1, \\
& 5 \quad, \quad=2 \text { inches. } \\
& 10,,=4 \quad, \\
& 15 \cdot 2, y=6, \\
& 20 \cdot 3, y=8, \\
& 25.4 \mathrm{~cm} .=10 \text { inches. } \\
& 30 \cdot 5,=12 \text {, } \\
& 35 \cdot 6, \quad=14, \\
& 40 \cdot 6,=16 \quad, \\
& 50 \cdot 8, \quad=20 \text {, } \\
& 100, \quad=39 \quad,
\end{aligned}
$$

